\title{
Lectotypification of two names in the family Convolvulaceae
}

\author{
Lawand P.R., Kattee A.V. \& V.B. Shimpale* \\ Department of Botany, The New College, Kolhapur, Maharashtra - 416 012, India. \\ *E-mail: shimpale@yahoo.com
}

\begin{abstract}
Argyreia daltonii C.B.Clarke and Ipomoea wightii (Wall.) Choisy are lectotypified here.

Keywords: Argyreia daltonii, Ipomoea wightii, Convolvulaceae, Lectotypification.
\end{abstract}

\section{Introduction}

The family Convolvulaceae is one of the dominant families of flowering plants, mainly distributed in the tropical and warm temperate regions of the World (Mabberley, 2017). Among the genera of Convolvulaceae in India, Ipomoea L. is the largest represented by 60 species (Kattee, 2019), while Argyreia Lour. comprises 35 species (Lawand, 2020). During revisionary studies of these two genera in India, it was noticed that Argyreia daltonii C.B.Clarke and Ipomoea wightii (Wall.) Choisy are yet to be lectotypified. The protologues of these two names and the type specimens deposited at BM, $\mathrm{CAL}$ and $\mathrm{K}$ were studied and lectotypified here following Art. 9.3 and 9.4 of the Shenzhen code (Turland et al., 2018).

\section{Typification}

Argyreia daltonii C.B.Clarke in Hook.f., Fl. Brit. India 4: 190. 1883. Lectotype (designated here): INDIA, Chota Nagpore [Jharkhand], Singhboom, Bundgao, 2000 feet, 28.10.1873, C.B.Clarke 20503D [K000830715 digital image!]; isolecto BM [BM000035627 digital image!], CAL [CAL0000018517 digital image!], K [K000830716, K001081782 digital images!].

Fig. 1

Received: 15.07.2020; Revised \& Accepted: 25.12.2020

Published Online: 31.12.2020
Notes: Argyreia daltonii was described by Clarke (1883) based on his collections from Chota Nagpore province of British India (presently the Jharkhand state in India). Six relevant collections were traced, four at K (K000830715, K000830717, K000830716 and K001081782), one each at BM (BM000035627) and CAL (CAL0000018517). All the specimens have handwritten labels by Clarke pertaining to collection details, agreeing with the protologue. The specimens predate the publication of the species

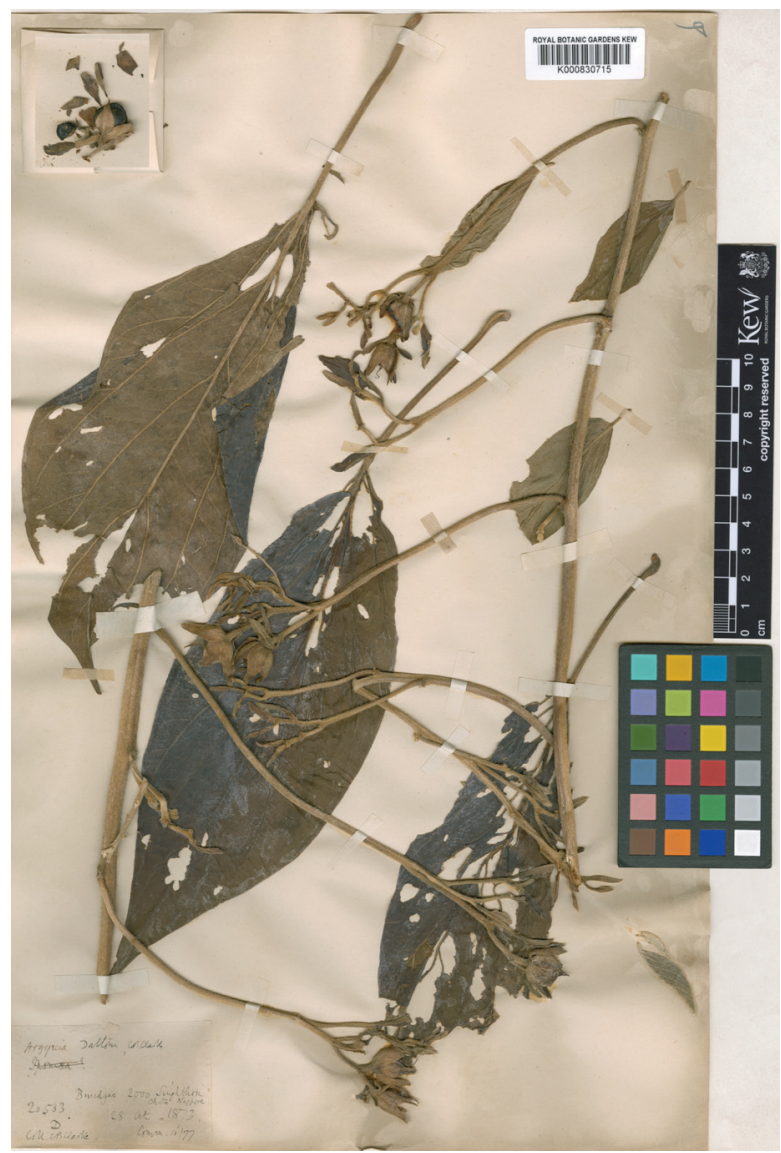

Fig. 1. Lectotype of Argyreia daltonii C.B.Clarke (K000830715). (C) The Board of Trustees for the Royal Botanic Gardens, Kew. Reproduced with permission. 
and can be regarded as original material. The specimen housed at K (K000830715) is with well preserved leaves, bracts and fruits which are key characters of the genus, hence it is selected here as the lectotype of the name $A$. daltonii.

Ipomoea wightii (Wall.) Choisy, Mém. Soc. Phys. Genève 6: 470. 1833. Convolvulus wightii Wall., Pl. As. Rar. 2: 55, t. 171. 1831. Lectotype (designated here): INDIA, Nilghery, HBC, 1827, R.Wight, Wall. Numer. List 1406.1 (K [K001113042 digital image!]).

Fig. 2

Notes: Wallich (1831) described Convolvulus wightii in honour of Robert Wight. This elegant and curious wild shrub was brought by Dr. Robert Wight from Nilgiri and grown at Calcutta Botanical Garden in 1826. According to Wallich catalogue list no. 1406 there are two specimens of C. wightii, one deposited at Kew (K001113042) labelled as 1406.1 and another at CAL (Acc. No. 311569) labelled as 'HBC, 1827 Nilghery'. The sheet at K (K001113042, digital image!), on which

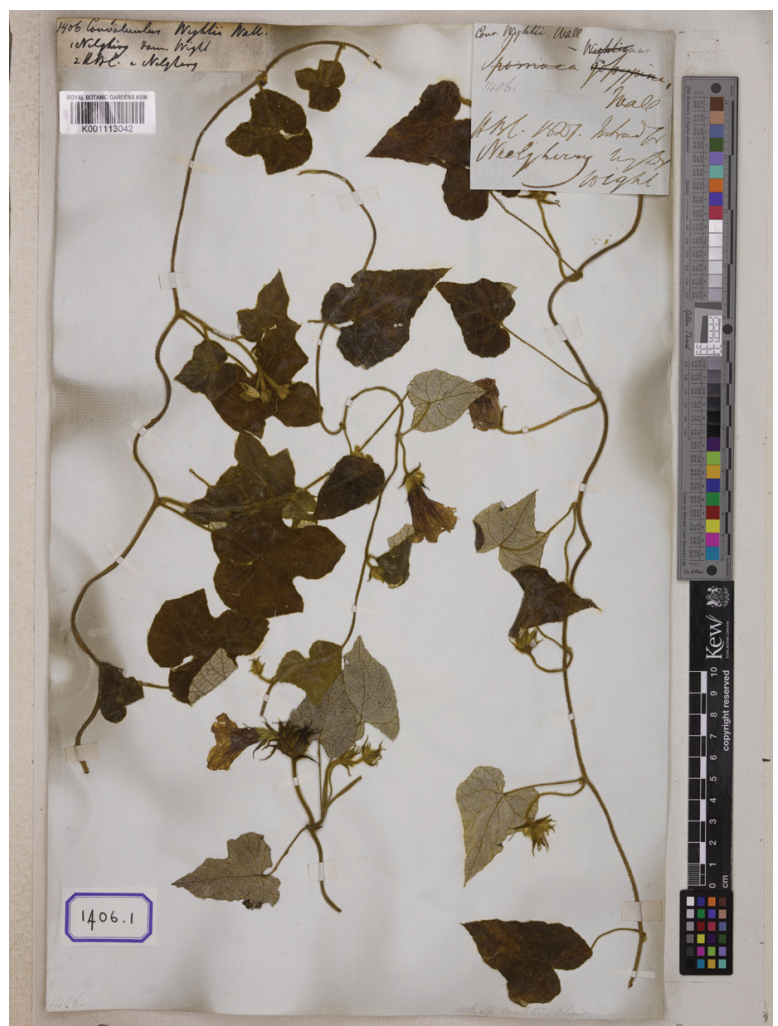

Fig. 2. Lectotype of Ipomoea wightii (Wall.) Choisy (K001113042). (C) The Board of Trustees for the Royal Botanic Gardens, Kew. Reproduced with permission. a handwritten label by Wallich is attached, matches well with the protologue. Wallich also noted observations on both wild as well as cultivated material and pointed out that both wild and cultivated material are abundantly covered with soft and spreading long hairs and the leaves are large, very soft and villous somewhat rugose which is evident in the sheet. Hence, the sheet K001113042 is designated here as the lectotype.

\section{Acknowledgements}

Authors are thankful to authorities of CAL for herbarium consultation and to the Principal, The New College, Kolhapur for necessary facilities. Thanks are extended to Dr. Sharad Kamble, Department of Botany, Maratha Vidya Prasarak Samaj's Arts, Commerce \& Science College, Tryambakeshwar for critical comments on the manuscript. AVK is thankful to BARTI, Pune and PRL is thankful to the CSIR for financial assistance.

\section{Literature Cited}

CLARKE C.B. 1883. Convolvulaceae. In: HOOKER J.D. (ed.), Flora of British India. Volume 4. L. Reeve and Co., London. pp. 184-196.

KATTEE A.V. 2019. Revision of genus Ipomoea L. (Convolvulaceae) from India. Ph.D. thesis (unpublished), Shivaji University, Kolhapur.

LAWAND P.R. 2020.Taxonomic revision of Argyreia Lour. (Convolvulaceae) from India. Ph.D. thesis (unpublished), Shivaji University, Kolhapur.

MABBERLEY D.J. 2017. Mabberley's Plant-Book: a portable dictionary of plants, their classification and uses. Fourth edition. Cambridge University Press, Cambridge.

TURLAND N.J., WIERSEMA J.H., BARRIE F.R., GREUTER W., HAWKSWORTH D.L., HERENDEEN P.S., KNAPP S., KUSBER W.H., LI D.Z., MARHOLD K., MAY T.W., MCNEILL J., MONRO A.M., PRADO J., PRICE M.J. \& G.F. SMITH (eds.) 2018. International Code of Nomenclature for algae, fungi, and plants (Shenzhen Code) adopted by the Nineteenth International Botanical Congress Shenzhen, China, July 2017. Regnum Vegetabile 159, Koeltz Botanical Books, Glashütten. https://doi.org/10.12705/ Code.2018

WALLICH, N. 1831. Plantae Asiaticae Rariores. Volume 2. Truettel and Wurtz, London. 